E3S Web of Conferences 1, 19003 (2013)

DOI: $10.1051 / \mathrm{e} 3$ sconf/20130119003

(c) Owned by the authors, published by EDP Sciences, 2013

\title{
Input of heavy metals to the forest floor as the result of zinc smelter pollution in southern Poland
}

\author{
K. Sawicka-Kapusta $^{1}$, M. Zakrzewska ${ }^{1}$, P. Dudzik $^{1}$ and K. Pietruszewska ${ }^{1}$ \\ ${ }^{1}$ Institute of Environmental Sciences, Jagiellonian University, Gronostajowa 7, 30-387 Kraków, POLAND, \\ katarzyna.sawicka-kapusta@uj.edu.pl
}

\begin{abstract}
The aim of this study was to assess the impact of zinc smelter on heavy metals concentration in the litter fall collected from three different sites in Olkusz Forest located in southern Poland. Furthermore the study was designed to investigate the input of these metals to the forest floor. Three forest areas Podlesie I and Podlesie II located 3 and $4 \mathrm{~km}$ south-east from Bukowno zinc smelter and Cegielnia situated $6 \mathrm{~km}$ north-east from the smelter were selected. At the beginning of September 2006 five litter traps were set at each site. The quantity of litter fall, along with percentage composition of each species, were estimated for an area of $1 \mathrm{~m}^{2}$. The concentration of $\mathrm{Cd}, \mathrm{Pb}, \mathrm{Cu}, \mathrm{Zn}$ and $\mathrm{Fe}$ in the litter fall and leaves of four main tree species were analysed. The input of these metals to the forest floor were determined. The input of cadmium ranged from 204 $\mu \mathrm{g} \mathrm{m}{ }^{2}$ at Cegielnia to $1340 \mu \mathrm{g} \mathrm{m}^{2}$ at Podlesie I. The input of lead was higher than cadmium and varied from $1031 \mu \mathrm{g} \mathrm{m}^{2}$ at Cegielnia to $3252 \mu \mathrm{g} \mathrm{m}^{2}$ at Podlesie II.The input of zinc and iron were about 10 times than cadmium and lead. The less input of all invesigated metals was noticed in control site located at WNP. for those metals. The high input of heavy metals to the forest floor may have negative effects on investigated part of Olkusz forest ecosystem.
\end{abstract}

Key words: zinc smelter, heavy metals, litter fall, input, forest floor

\section{Introduction}

In the last two decades of $20^{\text {th }}$ century industrial pollution and environmental degradation in Poland were one of the highest in Europe. The situation has improved considerably during last fifteen years (Nowicki 1993, Environment 2011). Quite new problem are the urban pollution, heavy traffic and low emmission. Still the potentially adverse effect of air pollution on the natural environment is expected close to industrial sources. Generally such problems are in Sląskie, Dolnośląskie, Małopolskie, Łodzkie and Wielkopolskie distric ts (Environment 2011). Bukowno zinc smelter located in Małopolska district in Southern Poland belongs to one of largest in country. In 1995 smelter emmitted $9600 \mathrm{~kg}$ of zinc, $5372 \mathrm{~kg}$ of lead and $511 \mathrm{~kg}$ of cadmium. Since 1995 emmission decreased and in 2006 reaached $1754 \mathrm{~kg}$ of zinc $34 \mathrm{~kg}$ of lead and $4 \mathrm{~kg}$ of cadmium (Pietruszewska 2007). Olkusz Forest situated in the western part of Małopolska district for a long time has been affected by industrial pollution from Bukowno zinc smelter and Upper Silesia Industrial Region. The effect of air pollutants on Olkusz Forest ecosystem has been studied during the past ten years. Some results of this investigation, concerning heavy metal accumulation in small mammals, transpalnted lichens and tree leaves shows contamination of this area. Also histopathological damage on rodents tissues, effects on population of invertebrates, and soil processess were also studied (Damek-Poprawa and Sawicka-Kapusta 2003, Białońska and Dayan 2005). The aim of this study was to estimate heavy metals concentration in the litter fall and the inputs of these metals to the forest floor that were due to air pollution from zinc smelter.

\section{Material and Methods}

Three forest areas in Olkusz Forest located in different distance from Bukowno zinc smelter and control site in Woliński National Park were selected. Two sites: Podlesie I and Podlesie II were located respectivly 3 and $4 \mathrm{~km}$ south-east from Bukowno zinc smelter 3 and $4 \mathrm{~km}$ respectivly and one: Cegielnia was situated $6 \mathrm{~km}$ northeast from the smelter. Control site was choosen in Wolinski National Park located in north-western part of Poland (Dudzik et al. 2010) At the beginning of 
September 2006 five litter traps were set at each site. Traps were constructed as $1 \mathrm{~m}^{2}$ frames, made of wood with nylon net (whole size:1/1 mm) bottom. After two months of exposure the litter was collected and sorted into different tree species. The quantity of litter fall, along with percentage composition of each species, were estimated for each of $1 \mathrm{~m}^{2}$ trap. The input of litter and

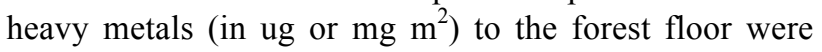
evaluated. The concentration of $\mathrm{Cd}, \mathrm{Pb}, \mathrm{Cu}, \mathrm{Zn}$ and $\mathrm{Fe}$ in the litter fall and in leaves of Querqus robur, Betula pendula, Fagus sylvatica and Pinus sylvestris were determined. Dry samples were wet digested in a $4: 1$ mixture of nitric and perchloric acid and the concentration of heavy metals $(\mathrm{Cd}, \mathrm{Pb}, \mathrm{Cu}, \mathrm{Zn}$ and $\mathrm{Fe}$ ) was analysed using atomic absorption spectrophotometer PerkinElmer AAnalyst 800 with graphit furnace for $\mathrm{Cd}$, $\mathrm{Pb}, \mathrm{Cu}$ and with flame for $\mathrm{Zn}$ and Fe (Damek-Poprawa and Sawicka-Kapusta 2003). Reference material (SRM $1573 \mathrm{~A})$ were also analysed. The recovy ranged from $98.8 \%$ to $105.1 \%$. Data are presented in $\mu \mathrm{g} \mathrm{g}^{1}$ dry weight. One way analyses of variance and post hoc Tukey test were used to determine the statistical differences in heavy metal concentration in the litter fall and metal input to the forest floor between sites.

\section{Results and Discussion}

Table 1 show the amount of litter input of different tree species at each investigated sites . Betula pendula, Fagus sylvatica, Quercus robur and Pinus sylvestris were present at all study sites in Olkusz Forest. Silver birch was not present at control area in Woliński National Park. Scots pine as the dominant tree at Cegielnia (25.7\%). European beech was the dominant species at two sites at Podlesie II (60.6\%) and Podlesie I (33.7\%). At control area also the dominant specie was european beech $(62.7 \%)$. The average litter fall ranged from $86.4 \mathrm{~g} \mathrm{~m}^{-2}$ at Cegielnia to $183.5 \mathrm{gm}^{-2}$ at Podlesie I. The highest litter fall $283.6 \mathrm{~g} \mathrm{~m}^{-2}$ was noticed at control site (Table 1).

Heavy metals concentration in the litter fall showed differences between the investigated forest sites. The lowest concentrations of each metals were noticed at control area and ranged from $0.23 \mu \mathrm{g} \mathrm{g}^{1}$ for cadmium to $92 \mu \mathrm{g} \mathrm{g}^{1}$ for iron. Cadmium concentration in mixed leaves ranged from $1.29 \mu \mathrm{g} \mathrm{g}^{1} \mathrm{~d}$.w.at Podlesie II to 7.30 $\mu \mathrm{g} \mathrm{g}{ }^{1}$ d.w. at Podlesie I. Statistical significant differences in cadmium concentration were found between each sites Statistially highest lead concentration $\left(18.93 \mu \mathrm{g} \mathrm{g}^{1}\right)$ from the others was found in the litter fall from Podlesie II.(Table 2) Zinc concentration $\left(145 \mu \mathrm{g} \mathrm{g}{ }^{1}\right)$ in the mixed leaves from Podlesie II was significantly lower than at Cegielnia and Podlesie I. Statistically highest iron concentration in the litter fall than in the two other sites was detected at Cegielnia (Table 3). Cadmium input to the forest floor ranged from $204 \mu \mathrm{g} \mathrm{m}^{-2}$ at Cegielnia to $1340 \mu \mathrm{g} \mathrm{m} \mathrm{m}^{-2}$ at Podlesie I. Statistical significant differences was found between Podlesie I and two other forest sites. The levels of lead input to the forest floor were significantly

Table 1. Average composition of litter fall in Olkusz Forest sites and in Woliński National Park (WNP) in 2006 [g and (\%) of different species].

\begin{tabular}{|c|c|c|c|c|}
\hline Species & Cegielnia & Podlesie I & Podlesie II & WNP (control) \\
\hline Betula pendula & $\begin{array}{c}89.2 \\
(20.6)\end{array}$ & $\begin{array}{l}13.4 \\
(1.5)\end{array}$ & $\begin{array}{l}36.0 \\
(4.2)\end{array}$ & - \\
\hline Fagus sylvatica & $\begin{array}{l}25.3 \\
(5.8)\end{array}$ & $\begin{array}{l}309.5 \\
(33.7)\end{array}$ & $\begin{array}{l}520.1 \\
(60.6)\end{array}$ & $\begin{array}{l}888.7 \\
(62.7)\end{array}$ \\
\hline Quercus robur & $\begin{array}{l}16.6 \\
(3.8)\end{array}$ & $\begin{array}{l}83.2 \\
(9.1)\end{array}$ & $\begin{array}{l}18.5 \\
(2.3)\end{array}$ & $\begin{array}{l}340.6 \\
(24.0)\end{array}$ \\
\hline Pinus sylvestris & $\begin{array}{l}111.1 \\
(25.7)\end{array}$ & $\begin{array}{l}116.3 \\
(12.7)\end{array}$ & $\begin{array}{l}242.3 \\
(28.2)\end{array}$ & $\begin{array}{l}188.8 \\
(13.3)\end{array}$ \\
\hline Quercus rubra & $\begin{array}{l}135.5 \\
(31.4)\end{array}$ & - & - & - \\
\hline Populus tremula & $\begin{array}{c}3.9 \\
(1.0)\end{array}$ & $\begin{array}{l}356.8 \\
(38.9)\end{array}$ & - & - \\
\hline Padus avium & $\begin{array}{l}29.1 \\
(6.7)\end{array}$ & $\begin{array}{l}10.2 \\
(1.1)\end{array}$ & - & - \\
\hline Larix decidua & $\begin{array}{c}9.0 \\
(2.1)\end{array}$ & $\begin{array}{l}19.6 \\
(2.1)\end{array}$ & $\begin{array}{l}37.3 \\
(4.2)\end{array}$ & - \\
\hline Others species & $\begin{array}{l}12.5 \\
(2.9)\end{array}$ & $\begin{array}{c}8.3 \\
(0.9)\end{array}$ & $\begin{array}{c}4.6 \\
(0.5)\end{array}$ & - \\
\hline$\sum[\mathrm{g}]$ & 432.2 & 917.3 & 858.8 & 1418.1 \\
\hline$\overline{\mathrm{X}}\left[\mathrm{g} \cdot \mathrm{m}^{-2}\right]$ & 86.4 & 183.5 & 171.8 & 283.6 \\
\hline
\end{tabular}


different between all sites and ranged from $1031 \mu \mathrm{g} \mathrm{m}^{-2}$ to 3252 lead $\mu \mathrm{g} \mathrm{m}^{-2}$ (Table 2). Input of zinc to the forest floor ranged from $25 \mathrm{mg} \mathrm{m}^{-2}$ in Podlesie II to $96 \mathrm{mg} \mathrm{m}^{-2}$ in Podlesie I. Input of this metal to the forest floor differed significantly between the sites in Olkusz Forest. The similar input of iron to the forest floor was in Podlesie I $\left(76 \mathrm{mg} \mathrm{m}^{-2}\right)$ and Podlesie II $\left(77 \mathrm{mg} \mathrm{m}^{-2}\right)$. These values were statistically higher then those found in Cegielnia (47 $\mathrm{mg} \mathrm{m}^{-2}$ ) (Table 3 ). The input of zinc and iron were about 10 times than cadmium and lead. The less input of all investigated metals was noticed in control site located at WNP. Generally the highest input of heavy metals to the forest floor were found in sites located close to Bukowno zinc smelter. The input of the same heavy metals to the forest floor at sites impacted by Cracow conurbation in years 1998-2000 and in Ratanica catchment was lower than those found in Olkusz Forest (Grodzińska and Laskowski 1996, Sawicka-Kapusta et.al. 2003). Our findings suggest that input of heavy metals to the forest floor in Olkusz Forest which is very high may have several negative effects on the forest ecosystem by affecting soil microorganisms, organic matter decomposition and other soil biological processes ( Laskowski et al 1993, Berg and Laskowski 2006).

Table 2. Average biomass of litter $\left(\mathrm{g} \cdot \mathrm{m}^{-2}\right)$, cadmium and lead concentrations $\left(\mu \mathrm{g} \cdot \mathrm{g}^{-1} \mathrm{~d} . \mathrm{w}.\right)$ in mixed leaves, and input of these metals to the forest floor in different sites in Olkusz Forest and in Woliński National Park (WNP).

\begin{tabular}{|c|c|c|c|c|c|}
\hline \multirow[b]{2}{*}{ Sites } & \multirow[b]{2}{*}{$\begin{array}{l}\text { Average } \\
\text { biomass of } \\
\text { litter }\end{array}$} & \multicolumn{2}{|c|}{ CADMIUM } & \multicolumn{2}{|l|}{ LEAD } \\
\hline & & $\begin{array}{l}\text { Concentration } \\
\text { in mixed leaves } \\
\mathrm{X} \pm \mathrm{SE}\end{array}$ & $\begin{array}{l}\text { Input to the } \\
\text { forest floor } \\
{\left[\mu \mathrm{g} \cdot \mathrm{m}^{-2}\right]}\end{array}$ & $\begin{array}{l}\text { Concentration } \\
\text { in mixed leaves } \\
\mathrm{X} \pm \mathrm{SE}\end{array}$ & $\begin{array}{l}\text { Input to the } \\
\text { forest floor } \\
{\left[\mu \mathrm{g} \cdot \mathrm{m}^{-2}\right]}\end{array}$ \\
\hline Cegielnia & 86.4 & $2.36 \pm 0.11^{\mathrm{a} 1}$ & $204 \pm 10^{\mathrm{a} 1}$ & $11.93 \pm 1.16^{\mathrm{a} 1}$ & $1031 \pm 99^{\mathrm{a} 1}$ \\
\hline Podlesie I & 183.5 & $7.30 \pm 0.34^{\mathrm{b} 1}$ & $1340 \pm 63^{b 1}$ & $13.60 \pm 0.91^{\mathrm{a} 1}$ & $2496 \pm 166^{\mathrm{b} 1}$ \\
\hline Podlesie II & 171.8 & $1.29 \pm 0.20^{\mathrm{c} 1}$ & $222 \pm 20^{\mathrm{a} 1}$ & $18.93 \pm 1.70^{b 1}$ & $3252 \pm 169^{\mathrm{cl}}$ \\
\hline WNP (control) & 283.6 & $0.23 \pm 0.03^{2}$ & $65 \pm 9.1^{2}$ & $0.99 \pm 0.01^{2}$ & $281 \pm 1.2^{2}$ \\
\hline \multicolumn{6}{|c|}{$\begin{array}{l}\text { a,b,c }- \text { the different letters indicate statistical differences between Olkusz Forest sites }(\mathrm{p}<0.5) \\
1,2 \text { - the different number indicate statistical differences between control and Olkusz Forest sites }(\mathrm{p}<0.5)\end{array}$} \\
\hline \multirow[b]{2}{*}{ Sites } & \multirow[b]{2}{*}{$\begin{array}{c}\text { Average } \\
\text { biomass of } \\
\text { litter }\end{array}$} & \multicolumn{2}{|c|}{ ZINC } & \multicolumn{2}{|c|}{ IRON } \\
\hline & & $\begin{array}{l}\text { Concentration } \\
\text { in mixed leaves } \\
\quad \mathrm{X} \pm \mathrm{SE}\end{array}$ & $\begin{array}{l}\text { Input to the } \\
\text { forest floor } \\
{\left[\mu \mathrm{g} \cdot \mathrm{m}^{-2}\right]}\end{array}$ & $\begin{array}{c}\text { Concentration } \\
\text { in mixed leaves } \\
\quad \mathrm{X} \pm \mathrm{SE}\end{array}$ & $\begin{array}{l}\text { Input to the } \\
\text { forest floor } \\
{\left[\mu \mathrm{g} \cdot \mathrm{m}^{-2}\right]}\end{array}$ \\
\hline Cegielnia & 86.4 & $431 \pm 16^{\mathrm{a} 1}$ & $37 \pm 1^{\mathrm{a} 1}$ & $543 \pm 22^{\mathrm{a} 1}$ & $471 \pm 2^{\mathrm{a} 1}$ \\
\hline Podlesie I & 183.5 & $521 \pm 21^{\mathrm{a} 1}$ & $96 \pm 4^{b 1}$ & $412 \pm 13^{b 1}$ & $76 \pm 2^{b 1}$ \\
\hline Podlesie II & 171.8 & $145 \pm 22^{b 1}$ & $25 \pm 2^{\mathrm{c} 1}$ & $451 \pm 22^{b 1}$ & $77 \pm 2^{b 1}$ \\
\hline WNP (control) & 283.6 & $23 \pm 2^{2}$ & $6 \pm 0.5^{2}$ & $92 \pm 4^{2}$ & $26 \pm 1^{2}$ \\
\hline
\end{tabular}

\footnotetext{
a,b,c - the different letters indicate statistical differences between Olkusz Forest sites $(\mathrm{p}<0.5)$

1,2 - the different number indicate statistical differences between control and Olkusz Forest sites $(\mathrm{p}<0.5)$
} 


\section{Conclusion}

Our surveys showed that Olkusz Forest is still impacted by the Bukowno zinc smelter emissions. The high input of heavy metals to the forest floor may have several negative effects on the investigated forest ecosystem.

\section{Acknowledgements}

The authors thank the financial supports providing from Institute of Environmental Studies, Jagiellonian University.

\section{References}

Berg B and Laskowski R. Litter decomposition: a guide to carbon and nutrient turnover. Academic Press Elsevier, Amsterdam, Boston, Heildelberg, London, New York, Oxford, Paris, San Diego, San Francisco, Singapore, Sydney, Tokyo 2006.

Białońska D and Dayan F.E. Chemistry of the lichen Hypogymnia physodes transpanted to an industrial region. Journal of Chemical Ecology 2005: 31: 2975-2991.

Damek-Poprawa M, Sawicka-Kapusta K. Damage of the liver, kidney and testis withreference to burden of havy metals in yellow-necked mice from areas around steelworks and zinc smelters in Poland. Toxicology 2003; 186: 1-10.

Dudzik P, Sawicka-Kapusta K, Tybik R, Pacwa K .Assessment of environmental pollution by metals sulphur dioxide and nitrogen in Woliński National Park. Monitoring Środowiska Przyrodniczego 2010; 11: 37-48.

Environment 2011. Statististical Information and Elaborations. Central Statistical Office, Warsaw 2011.

Grodzińska K and Laskowski R. Ocena środowiska i procesów zachodzących w lasach zlewni potoku Ratanica (Pogórze Wieleickie, Polska Południowa). Warszawa, Biblioteka Monitoringu Środowiska 1996.

Laskowski R. Maryański M, Niklińska M, Szarek G. Nutrient and heavy metal balance for litter in the mixed beech forest. Ekologia Polska 1993: 41:407-426.

Sawicka-Kapusta K, Zakrzewska M, Bajorek K, GdulaArgasińska J.Input of heavy metals to the forest floor as a result of Cracow urban pollution. Environment International 2003; 28:691-698. 